\title{
Aerobic and anaerobic decomposition of Pistia stratiotes leachates from a tropical eutrophic reservoir (Barra Bonita, SP, Brazil)
}

\author{
Bianchini Jr., I. ${ }^{\mathrm{a}, \mathrm{b}}$, Silva, RH. ${ }^{\mathrm{a}}$, Cunha-Santino, MB. ${ }^{\mathrm{a} *}$ and Panhota, RS. ${ }^{\mathrm{b}}$ \\ aDepartamento de Hidrobiologia - DHb, Universidade Federal de São Carlos - UFSCar, \\ Rod. Washington Luiz, Km 235, CEP 13565-905, São Carlos, SP, Brazil \\ 'Programa de Pós-Graduação em Ecologia e Recursos Naturais - PPGERN, \\ Universidade Federal de São Carlos - UFSCar, \\ Rod. Washington Luiz, Km 235, CEP 13565-905, São Carlos, SP, Brazil \\ *e-mail: irineu@ufscar.br \\ Received June 22, 2009 - Accepted October 1, 2009 - Distributed August 31, 2010
}

(With 2 Figures)

\begin{abstract}
The present study discussed the kinetic aspects of leachate decomposition from an aquatic macrophyte, Pistia stratiotes L (water lettuce). This species was collected from Barra Bonita Reservoir located in the State of São Paulo (Brazil). Decomposition chambers were prepared with high molecular weight (HMW), low molecular weight (LMW) and integral $(\mathrm{INT}=\mathrm{HMW}+\mathrm{LMW})$ dissolved organic matter (DOM) diluted with reservoir water. The samples were incubated at $20^{\circ} \mathrm{C}$, in darkness and under aerobic or anaerobic conditions. For 79 days, the concentrations of dissolved oxygen (DO) and organic carbon (OC) were measured. For calculating the deoxygenation coefficients $\left(\mathrm{k}_{\mathrm{d}}\right)$ and maximum oxygen consumption $\left(\mathrm{CO}_{\max }\right)$ the concentration of DO was integrated and fitted to a first-order kinetics model, which also applied to the depletion of OC concentrations. The $\mathrm{CO}_{\max }$ of INT incubations were $4 \%$ higher than the sum of HMW and LMW fractions. The deoxygenation coefficients, $\mathrm{k}_{\mathrm{d}}$, had the same order of magnitude for all treatments. In relation to carbon decay, regardless of the availability of oxygen, the INT DOM also showed higher mineralisation. These results suggest that the leachate mineralisations are short-term processes; when the fractionation of the leachates occurs, the LMW had organic compounds with more accessibility for heterotrophic metabolism. On the other hand, when compared to INT DOM, the HMW and LMW were less consumed suggesting an interaction of the reactivity of the leachate. Our data suggest that in the Barra Bonita Reservoir the mineralisation of P. stratiotes leachates occurs through two competitive pathways (i.e. mineralisation of the labile compounds and formation of recalcitrant organic resources and their mineralisation) in which the oxygen availability and the molecular mass of DOM can interfere in the rates of reactions.
\end{abstract}

Keywords: aquatic macrophyte, mineralisation, tropical reservoir, DOM, high and low molecular weight.

\section{Decomposição aeróbia e anaerobia de lixiviados de Pistia stratiotes de um reservatório eutrófico tropical (Barra Bonita, SP, Brasil)}

\begin{abstract}
Resumo
Nesse estudo foram discutidos aspectos cinéticos da decomposição de lixiviados da macrófita aquática Pistia stratiotes L (alface-d'água). A macrófita foi coletada no reservatório de Barra Bonita, localizado no Estado de São Paulo (Brasil). As câmaras de decomposição foram preparadas com amostras de água do reservatório e matéria orgânica dissolvida (MOD) de lixiviados com massa molecular alta (MMA), massa molecular baixa (MMB) e integral (INT = MMA + MMB). As amostras foram incubadas a $20^{\circ} \mathrm{C}$, no escuro e sob condições aeróbias e anaeróbias. Durante 79 dias, as concentrações de oxigênio dissolvido (OD) e de carbono orgânico (CO) foram determinadas. Para os cálculos dos coeficientes de desoxigenação $\left(\mathrm{k}_{\mathrm{d}}\right)$ e das quantidades máximas de oxigênio consumido $\left(\mathrm{OC}_{\max }\right)$, as concentrações de $\mathrm{OD}$ foram integradas e ajustadas a um modelo cinético de primeira ordem, que também foi empregado para os ajustes dos decréscimos das

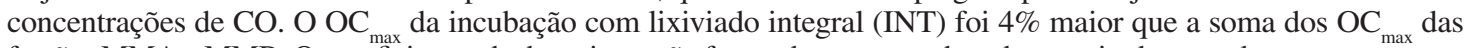
frações MMA e MMB. Os coeficientes de desoxigenação foram da mesma ordem de magnitude em todos os tratamentos. Em relação à perda de massa do carbono, independente da disponibilidade de oxigênio, a MOD INT apresentou as mineralizações mais elevadas. Os resultados sugeriram que as mineralizações desses lixiviados foram processos de curto prazo; na ocorrência de fracionamento, os lixiviados com MMB apresentam compostos orgânicos mais acessíveis aos metabolismos dos heterótrofos. Por outro lado, quando comparados com MOD INT, os lixiviados com MMB e MMA foram menos consumidos, sugerindo interação na reatividade dos lixiviados. Os resultados sugerem que no reservatório de Barra Bonita as mineralizações dos lixiviados de $P$. stratiotes ocorrem por duas rotas competitivas (i.e. mineralização dos compostos lábeis e formação de recursos refratários e sua mineralização), nas quais a disponibilidade de oxigênio e a massa molecular da MOD interferem nos coeficientes de reação.
\end{abstract}

Palavras-chave: macrófita aquática, mineralização, reservatório tropical, MOD, massa molecular alta e baixa. 


\section{Introduction}

In tropical aquatic systems macrophytes usually find favourable conditions for growth, being thus important for the carbon dynamics and cycles of nutrients (Wetzel, 1995). In the littoral zone, macrophyte communities exhibit high productivity, playing an important role in detritus production (Pieczynska, 1993). The metabolic routes associated with degradation of particulate organic matter (POM) and dissolved organic matter (DOM) can supply part of the energy required for the operation and stability of aquatic ecosystems (Wetzel, 1990). When degradation occurs in aerobic conditions, the main products are inorganic compounds with low energy; in the absence of oxygen, organic carbon is partially processed, forming intermediate substances with high energy content (Megonigal et al., 2004).

During decomposition of aquatic macrophytes, large amounts of hydrosoluble substances are released by leaching (e.g. 11 to 23\%; Peret and Bianchini Jr., 2004). These substances comprise organic compounds, e.g. carbohydrates, polyphenols, proteins, amino acids, and fatty acids, linked to inorganic elements such as $\mathrm{Ca}, \mathrm{N}$, and P; generally, humic substances comprise up 60-80\% of the total DOM (Steinberg and Münster, 1985). In aquatic environments, the DOM concentrations depend on how these substances are released (i.e. temporal variations of the leaching rates), the detritus origin, the physical properties of the medium and on the organisms involved in their decomposition (Wetzel, 2001). In addition to the chemical and physical interactions related with the DOM (e.g. light attenuation, sorption of dissolved constituents capacity; binding of xenobiotics) (Francko, 1990; Steinberger, 2003), this substance can represent a major carbon source for heterotrophic organisms, including bacteria, protozoa, and some algae. In this context, DOM usually comprises the main driving force for the microbial loop, promoting the growth of these microorganisms and the flux of carbon throughout the whole food web (Sigee, 2005). For determination of the chemical nature and dynamics of DOM, ultrafiltration techniques have been used to fractionate these compounds into different molecular masses (Hedges et al., 1994; Amon and Benner, 1996).

Considering the leachate of senescent aquatic plant tissue as an important autochthonous source of DOM, this study aims at describing and discussing the mineralisation of DOM with low and high molecular masses (under aerobic and anaerobic conditions). We also discuss the formation of recalcitrant substances from leachate of Pistia stratiotes Linnaeus, 1753 (water lettuce).

\section{Material and methods}

\subsection{Sampling site characterisation}

The Barra Bonita Reservoir is located at Tietê River in the central region of São Paulo State (22 $29^{\prime}$ to $22^{\circ} 32^{\prime}$ S and $48^{\circ} 29^{\prime}$ to $48^{\circ} 34^{\prime}$ W), Brazil. The river flow is an important force function of this system, where the changes in the hydrologic regime cause distinct ecological alterations (Tundisi and Matsumura-Tundisi, 1990). Limnological surveys indicate that the reservoir water is neutral-alkaline ( $\mathrm{pH} 7.43)$. It is a eutrophic system with high nutrient concentrations (P-total $=107 \mu \mathrm{g} . \mathrm{L}^{-1}$ and $\mathrm{N}$-total $\left.=1840 \mu \mathrm{g} . \mathrm{L}^{-1}\right)$ and high chlorophyll concentrations (76 $\left.\mu \mathrm{g} . \mathrm{L}^{-1}\right)$, which indicate high frequency of phytoplankton blooms (Calijuri and Santos, 2001). The eutrophication is considered an important issue in this environment (Tundisi et al., 1998).

\subsection{DOM collection and experimental design}

Samples of mature Pistia stratiotes individuals were collected in the littoral zone (ca. $3.0 \mathrm{~km}$ from the Barra Bonita dam). In the laboratory, the plants were washed with tap water, dried $\left(50{ }^{\circ} \mathrm{C}\right)$ until constant weight, triturated and the fragments were autoclaved (15 minutes, $1 \mathrm{~atm}$ and $121{ }^{\circ} \mathrm{C}$ ). For DOM extraction, about $30.0 \mathrm{~g}$ (DW) of grounded and sterilised fragments were immerged into 3.0 L of deionised (and autoclaved) water and maintained overnight at $4{ }^{\circ} \mathrm{C}$ (M $\phi 1 l e r$ et al., 1999). The fragments were then fractionated from deionised water by filtration in cellulose ester membrane $(0.45 \mu \mathrm{m}$; Millipore $)$, with the dissolved fraction being referred to as integral (INT) DOM. To accomplish the fractionation of INT DOM into low molecular masses (LMM) DOM and high molecular masses (HMM) DOM, an aliquot (ca. 2 L) of INT DOM was submitted to tangential ultrafiltration in hollow fibre cartridges (QSM Seriates, Quix System) with $10 \mathrm{kDa}$ membrane pores: DOM $>10 \mathrm{kDa}$ was classified as high molecular mass (HMM) and DOM $<10 \mathrm{kDa}$ as low molecular mass (LMM), according to Chaplin and Kennedy (1994).

After separation, the concentrations of dissolved organic carbon (DOC) were quantified to determine the percentage of HMM and LMM in INT DOM. The carbon determination was performed by combustion (Shimadzu, Model TOC 5000A); the proportion of HMM and LMM DOM was 38.7 and $61.3 \%$, respectively.

In order to prepare the mineralisation experiments, water samples taken at $5 \mathrm{~m}$ depth intervals were collected from littoral and pelagic zones with $5 \mathrm{~L}$ Van Dorn underwater samplers. Water samples were mixed in a polyethylene container to get vertically integrated indigenous microorganism samples. Immediately after collection, the samples were pre-filtered through a cellulose ester membrane $(0.45 \mu \mathrm{m})$ to attenuate predation pressures over bacterioplankton (Santos et al., 2007).

The mineralisation of different kinds of DOM was investigated by taking 24 mineralisation chambers by the dilution of different fractions of DOM (INT, HMM and $\mathrm{LMM}$ ) in reservoir water (DOC:water sample $\approx 1: 10$ ). The initial concentrations of DOC were: $\mathrm{HMM}=26.3 \mathrm{mg} . \mathrm{L}^{-1}$, $\mathrm{LMM}=30.8 \mathrm{mg} \cdot \mathrm{L}^{-1}$ and $\mathrm{INT}=36.1 \mathrm{mg} \cdot \mathrm{L}^{-1}$. The experiments were devised to test distinct mineralisation conditions: aerobic and anaerobic mineralisation of INT, HMM and LMM DOM and controls (chambers with reservoir water only). For each experimental category, two glass 
flasks $(250 \mathrm{~mL})$ and two controls were used; the flasks were maintained in the dark at $20^{\circ} \mathrm{C}$. Aerobic conditions (dissolved oxygen near saturation) were obtained by 1 hour oxygenation with filtered air. After oxygenation, the dissolved oxygen (DO) was measured by a DOmeter (YSI Model 58). When DO concentration reached 2.0 mg.L ${ }^{-1}$, the solutions were oxygenated again. Anaerobiosis was initially induced and maintained during the experiment by purging $\mathrm{N}_{2}$ into the anaerobic mineralisation chambers; after purging the DO concentrations were checked (DOmeter YSI Model 58).

\subsection{Setup for the oxygen uptake experiments}

The determination of oxygen consumption was performed periodically (days: $0,1,2,3,4,5,6,8,9,12,15,16,19,23$, $28,37,44$ and 79 ) by measuring the DO concentration using a polarometric oxygen probe (DOmeter YSI, Model 58). For each experimental category (INT DOM, HMM and LMM DOM), two glass flasks (ca. $300 \mathrm{~mL}$ ) and two controls (bottles with reservoir water only) were used, which were maintained in the dark at $20^{\circ} \mathrm{C}$. To avoid anaerobic degradation process, the mineralisation chambers were aerated whenever DO concentrations were close to $2.0 \mathrm{mg} . \mathrm{L}^{-1}$; after the oxygenation (with filtered air), the DO concentrations were measured again. The accumulated oxygen consumptions were obtained by integration of decreases in DO concentrations. For fitting the experimental data of consumed oxygen (CO) with the first-order kinetics model, use was made of a non linear regression method with the iterative algorithm of Levenberg-Marquardt (Press et al., 1993). The effect from chemical and biological oxidation was removed in the analysis of the kinetics of oxygen consumption by subtracting the oxygen consumptions from the control chambers that had water samples from the Barra Bonita Reservoir. The kinetics model was based on Equation 1 (Bianchini Jr. et al., 2008). To compare oxygen consumption of INT DOM mineralization with HMM and LMM DOM, the accumulated values of CO from HMM and LMM DOM mineralisations were normalised in relation to their proportion in INT DOM (HMM: 38.7\%; LMM: 61.3\%). Then, oxygen consumptions were estimated from the sum $(\mathrm{CO}-\mathrm{HMM} \mathrm{DOM} \times 0.39+\mathrm{CO}-\mathrm{LMM} \mathrm{DOM} \times 0.61)$. The half-time $\left(\mathrm{t}_{1 / 2}\right)$ of oxygen consumption was calculated according to Cunha-Santino et al. (2008).

$$
\mathrm{CO}=\mathrm{CO}_{\max }\left(1-\mathrm{e}^{-\mathrm{k}_{\mathrm{d}} \mathrm{t}}\right)
$$

where: $\mathrm{CO}=$ accumulated values of consumed oxygen $\left(\mathrm{mg} \mathrm{DO} \cdot \mathrm{g}^{-1} \mathrm{C}\right) ; \mathrm{CO}_{\max }=$ maximum amount of consumed oxygen $\left(\mathrm{mg}\right.$ DO. $\left.\mathrm{g}^{-1} \mathrm{C}\right) ; \mathrm{k}_{\mathrm{d}}=$ deoxygenation coefficient $\left(\mathrm{d}^{-1}\right)$ and $\mathrm{t}=$ time $(\mathrm{d})$.

\subsection{DOM mineralisation experiments (aerobic $e$ anaerobic conditions)}

The kinetics of mass loss for organic carbon $(\mathrm{OC}=$ dissolved + particulate fractions $)$ in all treatments and oxygen conditions was performed by sampling water aliquots (ca. $10 \mathrm{~mL}$ ) from mineralisation chambers, which had the carbon concentrations periodically (days: $0,1,2,3,4,5,6,8,9,12,15,16,19,28,37,44$ and 79) evaluated with a Shimadzu, Model TOC 5000A. The decrease in carbon concentration (crude sample) was fitted to first-order kinetic model (Equation 2) using a non linear regression method, the iterative algorithm of Levenberg-Marquardt (Press et al., 1993). The decreases of OC concentrations include two parallel processes: mineralisation (Equation 3) and the production of recalcitrant OC (ROC; e.g. microorganisms, humic substances, metabolic products) and their mineralisation (i.e. serial processes; Equation 4). The temporal variations of the mineralised carbon concentrations were estimated with Equation 5. The adopted kinetic models are the same that were used in similar experiments (Peret and Bianchini Jr., 2004; Cunha-Santino and Bianchini Jr., 2006a).

$$
\begin{aligned}
& \mathrm{OC}=\mathrm{DOC}_{0} \times \mathrm{e}^{-\mathrm{k}_{\mathrm{T}} \mathrm{t}} \\
& \mathrm{IN}_{1}=\frac{\mathrm{k}_{1}}{\mathrm{k}_{\mathrm{T}}} \times \mathrm{DOC}_{0} \times\left(1-\mathrm{e}^{-\mathrm{k}_{\mathrm{T}} \mathrm{t}}\right) \\
& \mathrm{IN}_{2}=\frac{\mathrm{k}_{2}}{\mathrm{k}_{\mathrm{T}}} \times \mathrm{DOC}_{0} \times\left[1+\frac{\mathrm{k}_{3}}{\mathrm{k}_{\mathrm{T}}-\mathrm{k}_{3}} \mathrm{e}^{-\mathrm{k}_{\mathrm{T}} \mathrm{t}}+\frac{\mathrm{k}_{\mathrm{T}}}{\mathrm{k}_{3}-\mathrm{k}_{\mathrm{T}}} \mathrm{e}^{-\mathrm{k}_{3} \mathrm{t}}\right] \\
& \mathrm{MOC}=\sum_{\mathrm{i}=1}^{2} \mathrm{IN}_{\mathrm{i}}
\end{aligned}
$$

where: $\mathrm{OC}=$ organic carbon $(\%) ; \mathrm{DOC}_{0}=$ initial amount of DOC (\%); MOC = mineralised organic carbon (\%); $\mathrm{t}=$ time $(\mathrm{d}) ; \mathrm{k}_{\mathrm{T}}=\mathrm{OC}$ global coefficient of mass loss $\left(=\mathrm{k}_{1}+\mathrm{k}_{2}\right), \mathrm{d}^{-1} ; \mathrm{k}_{1}=$ mineralisation coefficient of DOC labile fractions, $\mathrm{d}^{-1} ; \mathrm{k}_{2}=$ recalcitrant $\mathrm{OC}$ formation coefficient, $\mathrm{d}^{-1} ; \mathrm{k}_{3}=$ recalcitrant OC mineralisation coefficient, $\mathrm{d}^{-1} ; \mathrm{IN}_{1}$ and $\mathrm{IN}_{2}=$ inorganic carbon produced in each mineralisation route $(\%)$, the rates $\mathrm{k}_{1} / \mathrm{k}_{\mathrm{T}}$ and $\mathrm{k}_{2} / \mathrm{k}_{\mathrm{T}}$ defines the $\mathrm{IN}_{1}$ and $\mathrm{IN}_{2}$ yields, respectively.

The kinetics results for carbon depletion (HMM, LMM and INT DOM versus aerobic and anaerobic process) were submitted to the non parametric variance test (Kruskal-Wallis) and to Dunn's multiple comparison test. The statistical tests were applied to evaluate differences among treatments, with an alpha significance level of 0.05 .

With the parameterisation using the kinetics models, the temporal changes in $\mathrm{CO}$ (Equation 1) and MOC (Equation 4) were calculated. These functions were derived algebraically to estimate the daily rates of oxygen consumption and carbon oxidation. From the daily rates, the temporal variations of the stoichiometric relationships were calculated between the consumed oxygen and the oxidized carbon $(\mathrm{O} / \mathrm{C})$.

\subsection{Statistical analyses}

For each treatment, the kinetics fittings of $\mathrm{CO}$ were submitted to non-parametric variance test (Kruskal-Wallis) and to Dunn multiple comparison. The statistical tests were applied to evaluate the differences among the treatments (aerobic and anaerobic conditions versus HMM, LMM and INT DOM), with an alpha significance level of 0.05 being adopted. 


\section{Results}

\subsection{Oxygen uptake experiment}

The accumulated consumptions of oxygen from DOM mineralisation (INT, HMM and LMM) of $P$. stratiotes are presented in Figure 1, with the parameters used in the fitting being given in Table 1. Consumption was strong in the beginning of the experiment, up to the $20^{\text {th }}$ day, after which it tended to stabilise at the final stage of decomposition. In addition to the larger consumption in the first 5 days, another peak in consumption appeared between the $10^{\text {th }}$ and $20^{\text {th }}$ days.

Overall, the kinetics fittings derived higher determination coefficients ( $r^{2}: 0.97$ to 0.98 ) (Table 1$)$. From DOM oxidations, the consumptions of oxygen $\left(\mathrm{CO}_{\max }\right)$ (Table 1$)$ varied from $1713 \mathrm{mg} \mathrm{DO} \mathrm{g} \mathrm{C}{ }^{-1}$ (HMM) to $1992 \mathrm{mg} \mathrm{DO} \mathrm{g} \mathrm{C}^{-1}$ (LMM). The deoxygenation coefficients had close values, varying from $0.074 \mathrm{~d}^{-1}$ (HMM) to $0.087 \mathrm{~d}^{-1}$ (INT) and $\mathrm{t}_{1 / 2}$ were, respectively, 9.3 and 7.9 days.

In Figure 1 the stoichiometric relations computed from the daily rates of oxygen consumptions and oxidation of
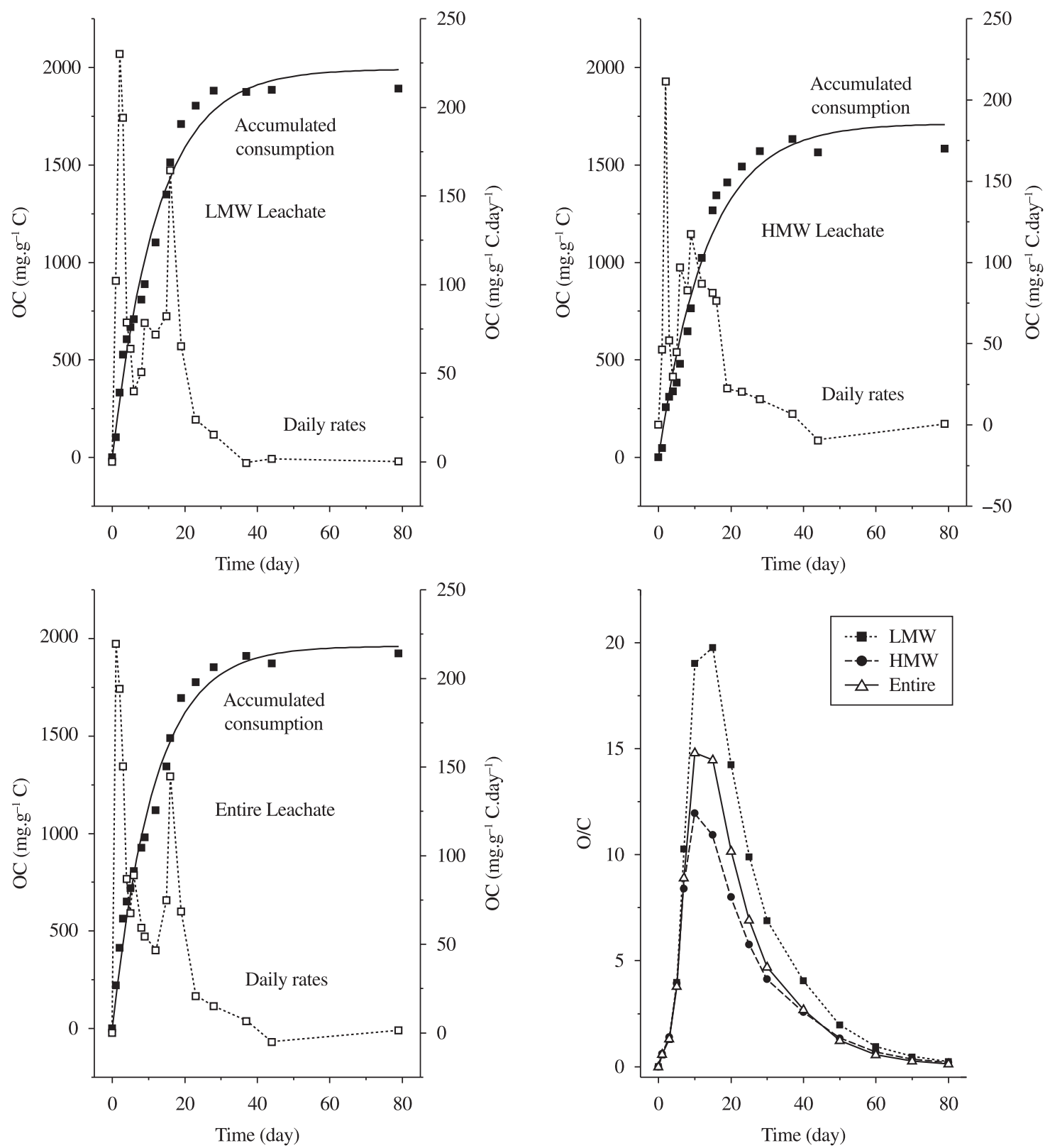

Figure 1. Kinetic fittings from oxygen consumption during aerobic mineralisation of Pistia stratiotes leachates (HMM: leachate with high molecular masses; LMM: leachate with low molecular mass) and temporal variation of the stoichiometric coefficients $(\mathrm{O} / \mathrm{C})$. 
Table 1. Parameters (values without the parenthesis) from decomposition models of Pistia stratiotes leachates (INT: entire leachate; HMM: leachate with high molecular masses; LMM: leachate with low molecular mass); the values in the parenthesis refer to errors from kinetic fittings.

\begin{tabular}{|c|c|c|c|c|c|c|}
\hline \multirow{3}{*}{$\begin{array}{c}\text { Parameter } \\
\mathrm{CO}_{\text {max }}\left(\mathrm{mg} \mathrm{DO} \mathrm{g}^{-1} \mathrm{C}\right) \\
\mathrm{k}_{\mathrm{d}}\left(\mathrm{d}^{-1}\right)\end{array}$} & \multicolumn{2}{|c|}{ INT } & \multicolumn{2}{|c|}{ LMM } & \multicolumn{2}{|c|}{ HМM } \\
\hline & 1961 & $(47)$ & 1992 & $(60)$ & 1713 & $(68)$ \\
\hline & 0.087 & $(0.005)$ & 0.080 & $(0.006)$ & 0.074 & $(0.007)$ \\
\hline $\mathrm{t}_{1 / 2}(\mathrm{~d})$ & 7.9 & & 8.7 & & 9.3 & \\
\hline$r^{2}$ & 0.98 & & 0.98 & & 0.97 & \\
\hline \multicolumn{7}{|c|}{ Aerobic process } \\
\hline $\mathrm{k}_{\mathrm{T}}\left(\mathrm{d}^{-1}\right)$ & 0.668 & $(0.101)$ & 0.688 & $(0.181)$ & 0.680 & $(0.226)$ \\
\hline $\mathrm{k}_{3}\left(\mathrm{~d}^{-1}\right)$ & 0.010 & $(0.002)$ & 0.006 & $(0.003)$ & 0.008 & $(0.002)$ \\
\hline $\mathrm{IN}_{1} *(\%)$ & 56 & & 55 & & 41 & \\
\hline $\mathrm{IN}_{2}(\%)$ & 44 & (2) & 45 & (3) & 59 & (3) \\
\hline $\mathrm{r}^{2}$ & 0.97 & & 0.88 & & 0.89 & \\
\hline \multicolumn{7}{|c|}{ Anaerobic process } \\
\hline $\mathrm{k}_{\mathrm{T}}\left(\mathrm{d}^{-1}\right)$ & 0.386 & $(0.039)$ & 0.360 & $(0.041)$ & 0.246 & $(0.065)$ \\
\hline $\mathrm{k}_{3}\left(\mathrm{~d}^{-1}\right)$ & 0.001 & $(0.002)$ & 0.007 & $(0.001)$ & 0.004 & $(0.003)$ \\
\hline $\mathrm{IN}_{1} *(\%)$ & 64 & & 52 & & 46 & \\
\hline $\mathrm{IN}_{2}(\%)$ & 36 & (2) & 48 & (2) & 54 & (5) \\
\hline $\mathrm{r}^{2}$ & 0.97 & & 0.96 & & 0.89 & \\
\hline
\end{tabular}

(*) The parameter $\mathrm{IN}_{1}$ did not present errors; these values were calculated by the difference between initial dissolved organic carbon concentration and the refractory organic carbon yields $\left(=\mathrm{IN}_{2}\right)$; thus, $\mathrm{IN}_{1}(\%)=100-\mathrm{IN}_{2}$.

carbon are also shown. The stoichiometric coefficients (O/C) varied as a function of elapsing time. However, regardless of the DOM type a common pattern was identified. An increase in the coefficients was observed in the initial phase, with the maximum at the $10^{\text {th }}$ day: 14.8 (INT), $15^{\text {th }}$ day: 19.8 (LMM) and $10^{\text {th }}$ day: 11.9 (HMM). Then, the coefficients decreased, tending to zero.

\subsection{DOM experiment mineralisation}

The kinetic fittings of the temporal DOC variations, under aerobic and anaerobic conditions, for INT, HMM and LMM DOM are presented in Figure 2. DOM decomposition had two stages: the first (ca. one week) is characterised by a fast decrease in mass, while the other had a slow mass decrease. The decreases in carbon concentrations for the treatment with INT DOM under aerobic and anaerobic conditions were significantly different from HMM under aerobic $(\mathrm{p}<0.05)$ and anaerobic conditions $(\mathrm{p}<0.01)$. However, LMW and INT treatments were similar $(\mathrm{p}>0.05)$, and the LMW and HWM DOM showed no significant differences $(\mathrm{p}>0.05)$.

The parameters used in the fitting the kinetics model (Equations 3 the 5) are shown in Table 1, which had higher determination coefficients $\left(r^{2}: 0.88\right.$ to 0.97$)$. The DOC global conversion coefficients $\left(\mathrm{k}_{\mathrm{T}}\right)$ were: $0.668 \pm 0.100 \mathrm{~d}^{-1}$ and $\mathrm{t}_{1 / 2}=1$ day (INT; aerobic condition); $0.688 \pm 0.181 \mathrm{~d}^{-1}$ and $\mathrm{t}_{1 / 2}=1$ day (LMW; aerobic condition) and $0.680 \pm 0.225 \mathrm{~d}^{-1}$ and $\mathrm{t}_{1 / 2}=1$ day (HMW; aerobic condition). For the mineralised DOM under anaerobic conditions the coefficients were respectively $0.386 \pm 0.038 \mathrm{~d}^{-1}\left(\mathrm{t}_{1 / 2}=2\right.$ days); $0.415 \pm 0.006 \mathrm{~d}^{-1}$ $\left(\mathrm{t}_{1 / 2}=2\right.$ days) and $0.246 \pm 0.065 \mathrm{~d}^{-1}\left(\mathrm{t}_{1 / 2}=3\right.$ days $)$.

\section{Discussion}

\subsection{Oxygen uptake experiment}

The determination coefficients $\left(\mathrm{r}^{2}\right)$ point to an adequate model using Equation 1 to describe the kinetics of oxygen consumption from DOM mineralisation. As far as the dynamics is concerned, oxygen consumption was similar to that of other experiments (Santos et al., 2006; Sciessere et al., 2007), regardless of the type of DOM (i.e. molecular masses). Based on a similar experiment that used DOM from Myriophyllum aquaticum and nitrapyrin (Nunes et al., 2007), we suppose that the later peaks of consumption in Figure 1 arose from oxidation of nitrogen compounds (i.e. nitrification); in this case, we inferred that LMM DOM had a higher concentration of amine compounds.

Taking into account that the mean residence time in Barra Bonita Reservoir is 132 days (from 52 (February) to 213 days (August); Panhota, 2007), in addition to the DOM photomineralisation (Santos et al., 2006; Soumis et al., 2007), the $\mathrm{t}_{1 / 2}$ suggests that oxidation of $P$. stratiotes DOM was a short-term process. Thus aerobic oxidation of DOM was fast in Barra Bonita Reservoir, being predominantly an autochthonous (i.e. is not exported) event. The accumulated oxygen consumptions within all the treatments were similar $(p>0.05)$, suggesting that DOM cycling - regardless of molecular masses - can support the energy demands of bacterioplankton growth in this environment. Different from that verified in our experiment, studies support the generalisation that the labile DOM pool is more important than the refractory DOM pool in sustaining bacterial secondary production (e.g. Amon and Benner, 1996). However, several recent studies that combined 

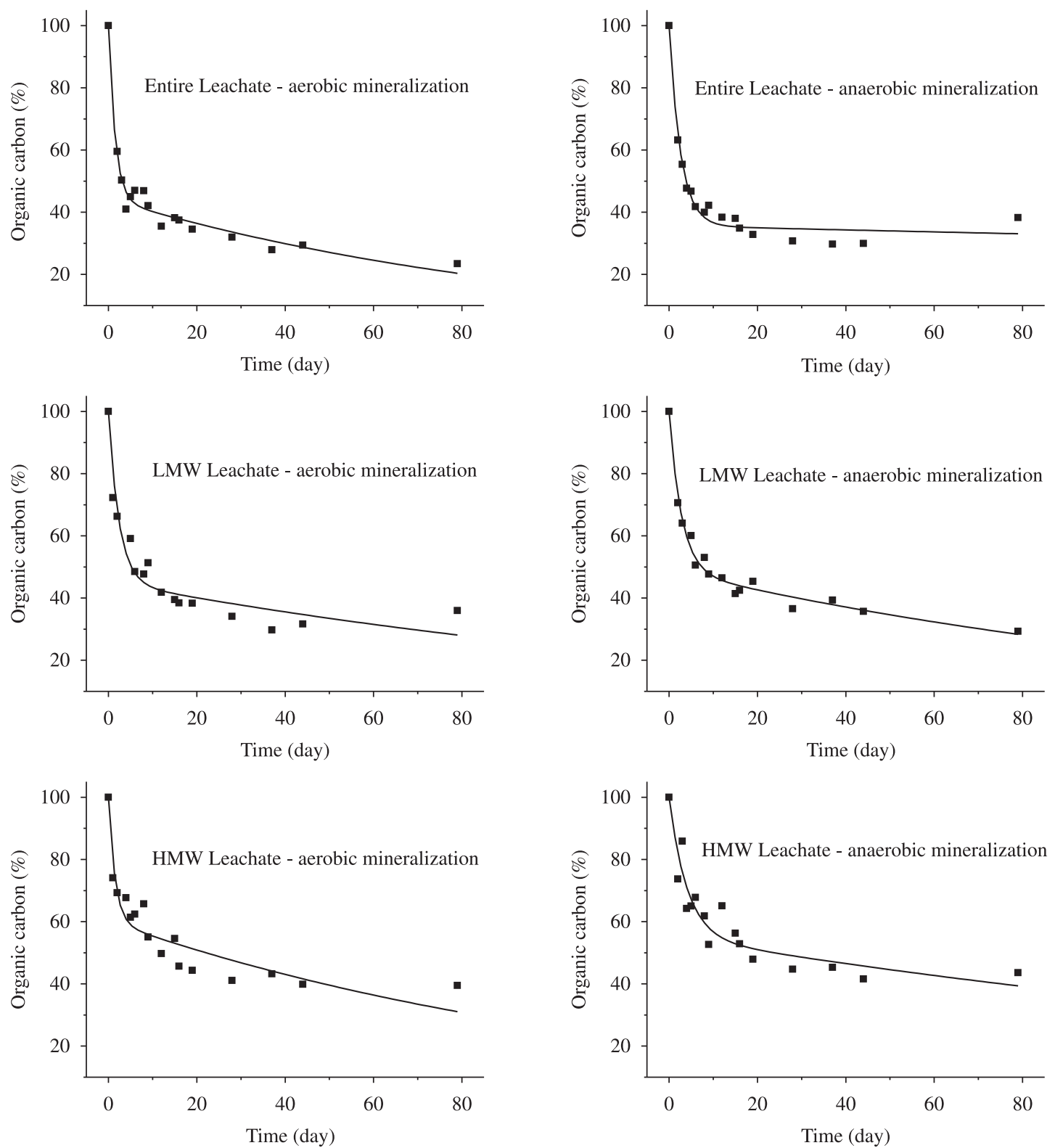

Figure 2. Temporal variation of dissolved organic carbon (DOC) derived from Pistia stratiotes leachates (HMM: DOM with high molecular masses; LMM: DOM with low molecular mass) under aerobic and anaerobic decompositions. The line refers to the kinetic fittings.

molecular microbial community analyses with DOM characterisation have called into question the generalisation that microorganisms predominantly metabolise the labile DOM fraction. On the contrary, DOM molecular weight may have less to do with productivity than the metabolic capabilities of the microbial community (Docherty et al., 2006). For example, bacterial growth upon humic lake water was limited mainly by concentration and not by molecular weight of the DOM (Eiler et al., 2003). Additionally, different microbial communities were present at high and low DOM concentrations. Members of the b-Proteobacteria and Cytophaga-flavobacter phyla were present at all DOM concentrations, whereas a-Proteobacteria dominated the lowest DOM concentrations (Eiler et al., 2003).

Because DOM and POM from aquatic macrophytes are heterogeneous biological resources from the chemical point of view (Peret and Bianchini Jr, 2004; Sciessere et al., 2007), we assume that decomposition and oxidation of the labile fractions predominated in the beginning, in a process with high oxygen demands. On the other hand, the decrease in oxygen consumptions was probably related to the mineralisation of recalcitrant fractions or to fractions with greater chemical stability and with less energy. In a study carried out with $P$. stratiotes DOM from the Barra 
Bonita Reservoir (Panhota, 2007) the mineralisation of LMM fractions also presented greater consumption of DO in relation to HMM. However, the values of consumption (HMM: $2233 \mathrm{mg} \mathrm{DO} \mathrm{g}^{-1} \mathrm{C}$ and LMM: $3024 \mathrm{mg} \mathrm{DO} \mathrm{g}^{-1} \mathrm{C}$ ) and $\mathrm{k}_{\mathrm{d}}$ were higher (HMM: $0.215 \mathrm{~d}^{-1}\left(\mathrm{t}_{1 / 2}=3\right.$ days) and LMM: $0.163 \mathrm{~d}^{-1}\left(\mathrm{t}_{1 / 2}=4\right.$ days). These higher values (CO and $\mathrm{k}_{\mathrm{d}}$ ) in comparison with the present study (Table 1) probably occurred from different samplings periods (distinct seasonal periods), samples of $P$. stratiotes in different phenologic stages, and samples of water reservoir used as inoculums, that induced the differentiation in the chemical composition of DOM and in the composition and the density of heterotrophic microbiota. However, these two studies indicated that DOM mineralisation of $P$. stratiotes in the Barra Bonita Reservoir is undoubtedly a short-term process with great potential to support the microbial loop (sensu Pomeroy and Wiebe, 1988).

In a compilation on distinct DOM mineralisation of oxygen consumption $(n=19)$ from aquatic macrophytes (Nunes et al., 2007), which adopted the same kinetics model used in this study (Equation 1), we observed that on average $\mathrm{CO}_{\max }$ was $1496 \mathrm{mg} \mathrm{DO} \mathrm{g}^{-1} \mathrm{C}$. The minimum $\mathrm{CO}_{\text {max }}$ was recorded for DOM mineralisation of Salvinia auriculata (256 mg DO g ${ }^{-1} \mathrm{C}$; Peret and Bianchini Jr, 2004), with the maximum value for Utricularia breviscapa (2123 mg DO g ${ }^{-1} \mathrm{C}$; Panhota et al., 2006). The $\mathrm{CO}_{\max }$ had large dispersion; in this type of experiment the contents of the reduced forms of carbon and nitrogen available were the factors governing the intensity of oxygen consumptions. Other factors that may have contributed to the oxygen consumption rates were (Cunha-Santino, 2003): (i) agitation from sampling handle during determination of DO concentrations; (ii) biochemical reactions generating hydrogen peroxide; (iii) chemolithotrophic processes; (iv) chemical oxidations (e.g. iron oxide formations) and (v) chemical composition of the resource (i.e. amount of intramolecular oxygen).

The mineralisation of DOM INT was $6 \%$ higher than the sum of consumptions of LMM and HMM DOM (considering the relative proportion of each fraction), thus suggesting synergy in the mineralisation processes. The concomitant existence of HMM and LMM compounds in INT DOM indicates a larger metabolic versatility of microorganisms. This event was similar to that verified in bacterial cultures prepared with DOM leached from aquatic macrophytes as the fresh DOM pool and DOM accumulated from a tropical humic lagoon (Farjalla et al., 2009). That experiment indicates that the mixture of fresh labile and accumulated refractory DOM that naturally occurs in aquatic ecosystems could accelerate the bacterial growth and bacterial DOM removal. The authors suggest that the differences in the concentration of some compounds between DOM sources, the co-metabolism on carbon compound decomposition, and the higher diversity of molecules possibly support a greater bacterial diversity which might explain the higher bacterial growth observed.

In the aerobic degradation, the oxidations are complete and the end products are inorganic, and we may assume that all the consumed oxygen is used in oxidation of organic compounds (Brezonik, 1994). Thus, the relation between the consumed oxygen and the oxidised carbon supply, in mass balance basis, provides the stoichiometric coefficients. The stoichiometric coefficients $(\mathrm{O} / \mathrm{C})$ varied with time in a pattern that did not depend on the DOM type. The same tendency was observed for aquatic macrophytes detritus (Cunha-Santino, 2003; Cunha-Santino and Bianchini Jr., 2006b). DOM mineralisation generates intense pressures of short-term period on the DO availability in aquatic systems; for the DOM in this study, the mineralisation of LMM compounds must consist of the main contributors for the oxygen demand, which presented the biggest quantity in the constitution of DOM (ca. 87\%), in addition to the highest stoichiometric relationship O/C. Experiments on aerobic mineralisation of barks, branches, leaves and litter showed similar patterns of temporal $\mathrm{O} / \mathrm{C}$ variation, registering maximum values $(6.73 ; 1.05 ; 2.45$ and 3.88 , respectively) on the $3^{\text {rd }}$ day suggesting that the high $\mathrm{O} / \mathrm{C}$ for degradation of barks is due to the chemical composition of the organic resource (Cunha-Santino and Bianchini Jr., 2002a). During the decomposition of aquatic macrophytes the following maximum values for $\mathrm{O} / \mathrm{C}$ coefficients were recorded: 5.03 (Montrichardia arborescens, maximum value: $17^{\text {th }}$ day; Cunha-Santino et al., 2004) and 11.05 (Salvinia auriculata, maximum value: $3^{\text {rd }}$ day; Cunha-Santino and Bianchini Jr., 2006b). The maximum values of the stoichiometric relationship, recorded in the first stages of decomposition, probably occurred from oxidations (chemical or biochemical) of the labile DOC, a fraction characterised by large diversity of reactive organic compounds. In the second stage, the changes in stoichiometric coefficients were probably related to biochemical oxidations (metabolic routes) of the recalcitrant fractions and to the diversity of heterotrophic microorganisms (density and species variations).

\subsection{DOM mineralisation}

The kinetics model was proven adequate to explain experimental data for mineralisation, as indicated by the high determination constants in the fittings shown in Table 1. It is concluded that mineralisation of $P$. stratiotes DOM occurred through two competitive processes (parallel). The first involves mineralisation of the labile compounds $\left(\mathrm{IN}_{1}\right)$, while the second route includes formation of recalcitrant organic compounds (ROC) and their mineralisation $\left(\mathrm{IN}_{2}\right)$. Based on the types of end products generated by decomposition (Amon and Benner, 1996; Cunha-Santino and Bianchini Jr., 2002b), we considered that ROC comprised mainly humic compounds and microbial biomass resulting from chemical and biochemical reactions of DOM mineralisation.

The DOC fast oxidations ( $\mathrm{IN}_{1}$ - Equation 3) varied from 41 (HMM; aerobic conditions) to 64\% (INT; anaerobic conditions; Table 1). The conversion yields of DOC to ROC $\left(\mathrm{IN}_{2}\right)$ varied from 36 (anaerobic conditions, INT) to $59 \%$ (aerobic conditions, HMM). The ROC formation was $7 \%$ higher in the treatments under aerobic conditions suggesting that the process is faster and favoured 
humification and particulate organic carbon formation (POC $\approx$ microorganisms). Also observed was that the fast oxidation route predominated under the two experimental conditions ( $\mathrm{IN}_{1}$ aerobic condition: $51 \%$ and anaerobic condition: $54 \%$ ). The intense losses of organic carbon in the initial stages were related to oxidation (chemical/ biological) of reactive dissolved compounds. The DOM decomposition followed a logarithm model (Strauss and Lamberti, 2002), and presents two stages, the first of which was characterised by a fast loss of mass followed by another with a slow mass decrease.

The size of the molecular mass from the organic compounds affects the mineralisation process strongly. In a decomposition experiment that utilised DOM from a riparian vegetation detritus, the HMM fractions were more labile and consequently more available for microorganisms (McArthur and Richardson, 2002). This was explained by considering that LMM compounds contain a larger quantity of polyphenols, and then the HMM fractions present a larger $\mathrm{C}: \mathrm{N}$ ratio. In contrast to the findings of McArthur and Richardson (2002), in our study the LMM DOM mineralisation under aerobic and anaerobic conditions produced higher yields after 79 days than the HMM DOM mineralisation. These results are similar to Panhota (2007), who observed intense mineralisation in LMM DOM, suggesting that this fraction has more available molecules to the bacterioplankton.

In our study, the heterotrophic community (under aerobic conditions) used efficiently the LMM and INT DOM, modifying the total dissolved carbon (in 79 days) into inorganic carbon (74 e 80\%, respectively). The efficiency of the HMM compounds transformation was lower, ca. $69 \%$ of the total carbon was transformed into inorganic carbon. These results were also found for anaerobic conditions. The HMM fractions had the lowest mineralisation efficiency $(61 \%)$, which may be explained by the smaller size then with larger surfaces for microorganism action - of the LMM compounds. However, the mineralisation of INT DOM under aerobic and anaerobic conditions was mineralised extensively. Weinbauer and Höfle (1998) also observed that DOC from INT fraction in a eutrophic lake (Plußsee, Germany) was more bio-reactive than the fractionated material. Experiments with enrichment of dissolved HMM and LMM organic compounds showed a development of distinct bacterial community that uses dissolved compounds (Covert and Moran, 2001). Hence, we assumed that the bacterial community that colonised the INT DOM utilised more efficiently the DOC, suggesting that the interaction of DOC, possibly presented a higher effect on the bio-reactivity then the fractionised compounds; this event could be responsible for the higher oxygen consumption observed in the incubations that contained non-fractionised DOM.

During anaerobic condition $\mathrm{k}_{\mathrm{T}}$ were lower than under aerobic conditions, indicating that oxygen availability selected heterotrophic community with higher efficiency in carbon metabolism, in both the speed of the process (1.94 times) as in the mineralisation yields (ca. 12\% higher for the aerobic process). In addition to the chemical characteristic of DOM, the community composition (Obernosterer et al., 2008) and density also could affect the mineralisation rate (Sigee, 2005).

The DOC mass loss observed in this study (aerobic and anaerobic conditions; LMM, HMM and INT) were higher than in similar experiments that considered DOM decomposition in the presence of POM $\left(0.370 \mathrm{~d}^{-1}\right.$ (Scirpus cubensis; aerobic condition), $0.196 \mathrm{~d}^{-1}$ (Cabomba piauhyensis; aerobic condition), $0.012 \mathrm{~d}^{-1}$ (Montrichardia arborescens; aerobic condition), $0.004 \mathrm{~d}^{-1}$ (Montrichardia arborescens; anaerobic condition), from 0.002 to $0.013 \mathrm{~d}^{-1}$ (Egeria najas; anaerobic condition) and from 0.004 to $0.005 \mathrm{~d}^{-1}$ (Eichhornia azurea; anaerobic condition; Cunha and Bianchini Jr., 1998; Bianchini Jr. et al., 2002; Bitar, 2003)) or POM absence (only DOM: Cabomba piauhyensis: $0.168 \mathrm{~d}^{-1}$; Cyperus giganteus: $0.206 \mathrm{~d}^{-1}$; Egeria najas: $0.252 \mathrm{~d}^{-1}$; Eichhornia azurea: $0.142 \mathrm{~d}^{-1}$; Salvinia auriculata: $0.299 \mathrm{~d}^{-1}$; Scirpus cubensis: $0.178 \mathrm{~d}^{-1}$; Utricularia breviscapa: $0.136 \mathrm{dia}^{-1}$; Peret and Bianchini Jr., 2004). Basically the higher coefficients derived from the composition and proportion of the labile compounds from the P. stratiotes DOM. These higher coefficients can also be attributed to the trophic state of environment (Corstanje et al., 2006) and the ability and composition of the microorganism (Docherty et al., 2006).

In the Barra Bonita Reservoir about $6.75 \%$ of the surface is occupied by aquatic macrophytes and $2 \mathrm{~km}^{2}$ of this surface is occupied by $P$. stratiotes (Carvalho et al., 2003). This species indicates eutrophic environments (Pott and Pott, 2000) and in favourable conditions presents a fast propagation, with predominance of vegetative reproduction (Bezerra and França, 1999). In tropical environments, there is a low duplication time (e.g. 22 days; Henry-Silva et al., 2002) and high density (881.2 $\mathrm{g} \mathrm{DW} \mathrm{m}^{-2}$; Moraes (1999); $205.3 \mathrm{~g} \mathrm{DW} \mathrm{m}^{-2}$; Camargo and Florentino (2000); 220-324 g DW $\mathrm{m}^{-2}$, Camargo and Biudes (2006)) for P. stratiotes, with the ideal temperature for growth lying between 22 and $30{ }^{\circ} \mathrm{C}$ (Kasselmann, 1995). Furthermore, the high growth potential of this plant, the high temperatures and the adequate nutritional conditions (usually found in this environment) indicate the importance of aquatic macrophytes, and in particular, of $P$. stratiotes as a detritus source in the reservoir.

The leaching of $P$. stratiotes detritus generated $27.9 \%$ (in DW) soluble compounds (Panhota, 2007). Taking this together with the incident surface area of this species and its density, we may infer that in the Barra Bonita Reservoir, the DOM liberation potential of $P$. stratiotes detritus is between 103.1 and 442.4 t (16.1 and 69.0 t, in C basis). Therefore, this DOM is as an important autochthonous DOC source. We also verified that, regardless of oxygen availability, about $52 \%$ of this DOM had fast mineralisation (average $\mathrm{t}_{1 / 2}: 1.4$ day), supporting the metabolic process of the bacterioplankton. In the Barra Bonita Reservoir, the DOM supporting the microbial metabolism probably presented a higher short-term impact upon the carbon cycle than the processes favouring ROC formation. This is because 
the recalcitrant products, due to the low mineralisation coefficients (average $t_{1 / 2}$ process: aerobic $=90$ days; anaerobic $=322$ days , tended to accumulate in the sediment, being transferred to the long-term cycling process. These processes are linked to the life cycles of aquatic plants. In summary, in the Barra Bonita Reservoir, the effects derived from leachates of the $P$. stratiotes and on its consumption by the community of decomposers depend on the hydrologic cycle, on the seasonal growth and senescence of $P$. stratiotes. In this context, our data suggest that in the Barra Bonita Reservoir the mineralisation of $P$. stratiotes leachate is a fast process that occurs through two competitive pathways. The first involves mineralisation of the labile compounds, while the second route includes formation of recalcitrant organic resources (i.e. humic compounds and microbial biomass) and their mineralisation. In addition to oxygen availability, the molecular mass of plant leachate can interfere in the rates of mineralisation.

Acknowledgements - The authors thank CNPq (processes $\mathrm{n}^{\text {o: }}$ 300959/2004-4; 150169/2004-3 and 302935/2007-0). We are also indebted to Dr. O. N. Oliveira Jr. (IFSC-USP) for his critical proofreading of the manuscript and to anonymous reviewers for their suggestions.

\section{References}

AMON, RMW. and BENNER, R., 1996. Bacterial utilization of different size classes of dissolved organic matter. Limnology and Oceanography, vol. 41, no. 1, p. 41-51.

BEZERRA, MG. and FRANÇA, F., 1999. Arales de lagoas de uma área do semi-árido bahiano. Sitientibus, vol. 20, no. 1, p.45-54.

BIANCHINI Jr., I., CUNHA-SANTINO, MB. and PERET, AM., 2008. Oxygen demand during mineralization of aquatic macrophytes from an oxbow lake. Brazilian Journal of Biology, vol. 68 , no. 1, p. 61-67.

BIANCHINI Jr., I., PACOBAHYBA, LD. and CUNHA-SANTINO, MB., 2002. Aerobic and anaerobic decomposition of Montrichardia arborecens (L.) Schott. Acta Limnologica Brasiliensia, vol. 14, no. 3, p. 27-34.

BITAR, AL., 2003. Mineralização e formação de gases da degradação de Eichhornia azurea Kunth and Egeria najas Planch. São Carlos: Universidade Federal de São Carlos. [Tese de Doutorado]

BREZONIK, PL., 1994. Chemical kinetics and process dynamics in aquatic systems. Boca Raton: Lewis. $754 \mathrm{p}$.

CALIJURI, MC. and SANTOS, ACA., 2001. Temporal variations in phytoplankton primary production in a tropical reservoir (Barra Bonita, SP - Brazil). Hydrobiologia, vol. 445, no. 1-3, p. 11-26.

CAMARGO, AFM. and BIUDES, JFV., 2006. Influence of limnological characteristics of water in the occurrence of Salvinia molesta and Pistia stratiotes in the rivers from Itanhaém River basin (SP, Brazil). Acta Limnologica Brasiliensia, vol. 18, no. 3, p. 239-246.

CAMARGO, AFM. and FLORENTINO, ER., 2000. Population dynamics and net primary production of aquatic macrophyte Nymphaea rudgeana C. F. Mey in a lotic environment of the
Itanhaém River basin (SP, Brazil). Brazilian Journal of Biology, vol. 60 , no. 1, p. 83-92.

CARVALHO, FT., GALO, MLBT., VELINI, ED. and MARTINS, D., 2003. Plantas aquáticas e nível de infestação das espécies presentes no reservatório de Barra Bonita, Rio Tietê. Planta Daninha, vol. 21, no. special, p. 15-19.

CHAPLIN, MF. and KENNEDY, JF., 1994. Carbohydrate analysis: a practical approach. Oxford: Irl Press. 324 p.

CORSTANJE, R., REDDY, KR. and PORTIER, KM., 2006. Thypha latifolia and Cladium jamaicense litter decay in response to exogenous nutrient enrichment. Aquatic Botany, vol. 84, no. 1, p. $70-78$

COVERT, JS. and MORAN, MA., 2001. Molecular characterization of estuarine bacterial communities that use high- and low - molecular weight fraction of dissolved organic carbon. Aquatic Microbial Ecology, vol. 25, no. 2, p. 127-139.

CUNHA, MB. and BIANCHINI Jr., I., 1998. Mineralização aeróbia de Cabomba piauhyensis e Scirpus cubensis. Acta Limnologica Brasiliensia, vol. 10, no. 1, p. 81-91.

-, 2002a. Estequiometria da decomposição aeróbia de galhos, cascas, serapilheira e folhas. In ESPÍNDOLA, ELG., MAUAD, FF., SCHALCH, V., ROCHA, O., FELICIDADE, N. and RIETZLER, AC. (Eds.). Recursos Hidroenergéticos: usos, impactos e planejamento integrado. São Carlos: Rima. p. 43-55. (Série Ciências da Engenharia Ambiental, vol. 1)

-, 2002b. Humic substance mineralization in a tropical oxbow lake (São Paulo, Brazil). Hydrobiologia, vol. 468, no. 1-3, p. 33-43.

-, 2006a. Formação e mineralização de lixiviados de duas macrófitas aquáticas da Lagoa do Óleo (Estação Ecológica de Jataí, Luiz Antônio, SP, Brasil). In SANTOS, JE., PIRES, JSR. and MOSCHINI, LE. (Eds.). Estudos integrados em ecossistemas. São Carlos: EdUFSCar. p. 170-187. (vol. 4)

-, 2006b. Consumo de oxigênio e estequiometria da decomposição aeróbia de Utricularia breviscapa Wright ex Griseb e Salvinia auriculata Aubl. In SANTOS, JE., PIRES, JSR. and MOSCHINI, LE. (Eds.). Estudos integrados em ecossistemas. São Carlos: EdUFSCar. p. 189-203. (vol. 4)

CUNHA-SANTINO, MB., 2003. Atividade enzimática, cinética e modelagem matemática da decomposição de Utricularia breviscapa da lagoa do Óleo (Estação Ecológica de Jataí, Luiz. Antônio-SP). São Carlos: Universidade Federal de São Carlos. [Tese de Doutorado].

CUNHA-SANTINO, MB., GOUVÊA, SP., BIANCHINI Jr., I. and VIEIRA, AAH., 2008. Oxygen uptake during mineralization of photosynthesized carbon from phytoplankton of Barra Bonita Reservoir: a mesocosm study. Brazilian Journal of Biology, vol. 68 , no. 1, p. 123-130.

CUNHA-SANTINO, MB., PACOBAHYBA, LD. and BIANCHINI Jr., I., 2004. O/C stoichiometry from mineralization of Montrichardia arborescens (L.) Schott. Acta Limnologica Brasiliensia, vol. 16, no. 4 , p. 351-357.

DOCHERTY, KM., YOUNG, KC., MAURICE, PA. and BRIDGHAM, SD., 2006. Dissolved organic matter concentration and quality influences upon structure and function of freshwater microbial communities. Microbial Ecology, vol. 22, no. 3, p. 378-388.

EILER, A., LANGENHEDER, S., BERTILSSON, S. and TRANVIK, LJ., 2003. Heterotrophic bacterial growth efficiency and community structure at different natural organic carbon 
concentrations. Applied and Environmental Microbiology, vol. 69, no. 7, p. 3701-3709.

FRANCKO, DA., 1990. Alteration of bioavailability and toxicity by phototransformation of organic acids. In PERDUE, EM. and GJESSING, ET. (Eds.). Organic acids in aquatic ecosystems. Chichester: Wiley. p. 167-177.

HEDGES, JI., COWIE, GL., RICHEY, JE., QUAY, PD., BENNER, R., STROM, M. and FORSBERG, BR., 1994. Origins and processing of organic matter in the Amazon River as indicated by carbohydrates and amino acids. Limnology and Oceanography, vol. 39 , no. 4 , p. $743-761$

HENRY-SILVA, GG., CAMARGO, AFM. and PEZZATO, MM., 2002. Effect of nutrient concentrations on the growth of aquatic macrophytes Eichhornia crassipes, Pistia stratiotes and Salvinia molesta. In Proceeding of the 11 EWRS International Symposium on Aquatics Weeds, Moliets et Maâ. France. p. 147-150.

KASSELMANN, C., 1995. Aquarienpflanzen. Stuttgart: Egen Ulmer GMBH \& Co. 472 p.

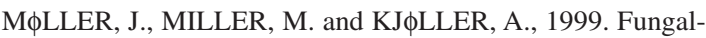
bacterial interaction on beech leaves: influence on decomposition and dissolved carbon quality. Soil Biology and Biochemistry, vol. 31 , no. 3 , p. $367-374$.

McARTHUR, MD. and RICHARDSON, JS., 2002. Microbial utilization of dissolved organic carbon leached from riparian litterfall. Canadian Journal of Fisheries and Aquatic Sciences, vol. 59, no. 10, p. 1668-1676.

MEGONIGAL, JP., HINES, ME. and VISSCHER, PT., 2004. Anaerobic metabolism: linkages to trace gases. In SCHLENSINGER, WH. (Ed.). Biogeochemistry. Oxford: Elsevier-Pergamon. p. $317-424$.

MORAES, AJ., 1999. Estimativa de estoque de elementos químicos em macrófitas aquáticas do reservatório de Salto Grande (Americana, SP). São Carlos: Universidade Federal de São Carlos. [Dissertação de Mestrado]

NUNES, MF., CUNHA-SANTINO, MB. and BIANCHINI Jr., I., 2007. Aerobic mineralization of carbon and nitrogen from Myriophyllum aquaticum (Vell.) Verdc. leachate. Acta Limnologica Brasiliensia, vol. 19, no. 3, p. 285-293.

OBERNOSTERER, I., CHRISTAKI, U., LEFÈVRE, D., CATALA, P., WAMBEKE, F. van and LEBARON, P., 2008. Rapid bacterial mineralization of organic carbon produced during a phytoplankton bloom induced by natural iron fertilization in the Southern Ocean. Deep-Sea Research: Topical Studies in Oceanography, vol. 55, no. $5-7$, p. 777-789.

PANHOTA, RS., 2007. Utilização e destino do carbono orgânico dissolvido em um reservatório eutrófico (Barra Bonita, SP). São Carlos: Universidade Federal de São Carlos. [Tese de Doutorado]

PANHOTA, RS., CUNHA-SANTINO, MB. and BIANCHINI Jr., I., 2006. Consumos de oxigênio das minarealizações de lixiviados de Salvinia auriculata e Ultricularia breviscapa da Lagoa do Óleo. In SANTOS, JE., PIRES, JSR and MOSCHINI, LE. (Eds.). Estudos integrados em ecossistemas. São Carlos: EdUFSCar. p. 259-273. (vol. 4)

PERET, AM. and BIANCHINI Jr., I., 2004. Stoichiometry of aerobic mineralization $(\mathrm{O} / \mathrm{C})$ of aquatic macrophytes leachate from a tropical lagoon (São Paulo, Brazil). Hydrobiologia, vol. 528, no. 1-3, p. 167-178.
PIECZYNSKA, E., 1993. Detritus and nutrient dynamics in the shore zone of lakes: a review. Hydrobiologia, vol. 251, no. 1-3, p. 49-58.

POMEROY, LR. and WIEBE, WJ., 1988. Energetic of microbial food webs. Hydrobiologia, vol. 159, no. 1, p. 7-18.

POTT, VJ. and POTT, A., 2000. Plantas aquáticas do Pantanal. Brasília: Embrapa. 404 p.

PRESS, WH., TEUKOLSKY, SA., VETTERLING, WT. and FLANNERY, BP., 1993. Numerical recipes in C: the art of scientific computing. New York: Cambridge University Press. 994 p.

SANTOS, MG., CUNHA-SANTINO, MB. and BIANCHINI Jr., I., 2007. Methodological test of efficiency of heterotrophic potential. Acta Scientiarum. Biological Sciences, vol. 29, no. 2, p. $197-201$

SCIESSERE, L., CUNHA-SANTINO, MB. and BIANCHINI Jr., I., 2007. Detritus age on aerobic mineralization of Salvinia auriculata Aubl. Acta Limnologica Brasiliensia, vol. 19, no. 1, p. 43-51.

SIGEE, DC., 2005. Freshwater microbiology. Chichester: Wiley. $524 \mathrm{p}$.

SOUMIS, N., LUCOTTE, M., LAROSE, C., VEILLETTE, F. and CANUEL, R., 2007. Photomineralization in a boreal hydroelectric reservoir: a comparison with natural aquatic ecosystems. Biogeochemistry, vol. 86, no. 2, p. 123-135.

STEINBERG, CEW. and MÜNSTER, U., 1985. Geochemistry and ecological role of humic substances in lakewater. In AIKEN, GR., MCKNIGHT, DM., WERSHAW, RL. and MCCARTHY, P. (Eds.). Humic substances in soil, sediment, and water. New York: Wiley. p. 105-145.

STEINBERG, CEW., 2003. Ecology of humic substances in freshwaters. Berlin: Springer-Verlag. $440 \mathrm{p}$.

STRAUSS, EA. and LAMBERTI, GA., 2002. Effect on dissolved organic carbon quality on microbial decomposition and nitrification rates in stream sediments. Freshwater Biology, vol. 47, no. 1, p. 65-74.

TUNDISI, JG. and MATSUMURA-TUNDISI, T., 1990. Limnology and eutrophication of Barra Bonita Reservoir, S. Paulo State, Southern Brazil. Archiv für Hydrobiologie Beihefte Ergebnisse der Limnologie, no. 33, p. 661-676.

TUNDISI, JG., ROCHA, O., MATSUMURA-TUNDISI, T. and BRAGA, B., 1998. Reservoir Management in South America. Water Resources Development, vol. 14, no. 2, p. 141-155.

WEINBAUER, MG. and HÖFLE, MG., 1998. Distribution and life strategies of two bacterial populations in a eutrophic lake. Applied and Environmental Microbiology, vol. 64, no. 10, p. 3776-3783.

WETZEL, RG., 1990. Detritus, macrophytes and nutrient cycling in lakes. Memorie dell'Istituto Italiano di Idrobiologia, vol. 47, p. $233-249$

-, 1995. Death, detritus and energy flow in aquatic ecosystems. Freshwater Biology, vol. 33, no. 1, p. 83-89.

-, 2001. Limnology: lake and river ecosystems. 3 ed. San Diego: Academic Press. 1006 p. 